\title{
In "Virtual Dialogue" with the Somali Community: The Value of Electronic Media for Research amongst Refugee Diasporas
}

\author{
Cindy Horst
}

\begin{abstract}
This article illustrates the methodological potential of electronic media such as the Internet and e-mail for research amongst refugee diasporas. It will first describe research amongst Somalis in Kenyan refugee camps, which demonstrated the importance of transnational networks in the survival of refugees in the camps. The intention of the research set-up was to provide an alternative approach to common depictions of refugees, which often ignore their agency. A focus on agency, referring to every individual's level of choice and power, is as much a methodological decision as a theoretical or epistemological assumption, since people's agency clearly manifests itself in knowledge creation. After describing the possible dialogical nature of academic knowledge creation, the article moves on to illustrate how electronic media can play an important role in this. There are a number of apparent advantages to the methodological use of the Internet and e-mail in research, though at the same time pitfalls should not be underestimated. Nevertheless, when studying refugee communities that are dispersed across the globe and make active use of electronic media, "virtual dialogues" provide fascinating new insights.
\end{abstract}

\section{Résume}

L'article illustre le potentiel méthodologique de médias comme l'Internet et le courriel pour la recherche parmi les diasporas de réfugiés. Il se concentre d'abord sur les Somaliens dans les camps kényans de réfugiés, ce qui prouve l'importance des réseaux transnationaux relativement à la survie des réfugiés dans les camps. La recherche visait à fournir une approche différente des descriptions habituelles de réfugiés, qui ignorent souvent leurs droits. Le fait de mettre l'accent sur ceux-ci, qui renvoie au degré de choix et de pouvoir de chaque personne, est autant une décision d'ordre méthodologique qu'une hypothèse théorique ou épistémologique, puisque les droits du peuple se manifestent clairement dans la création de la connaissance. Après avoir décrit la nature dialogique possible de la création de la connaissance académique, l'article poursuit en montrant comment les médias électroniques peuvent jouer un rôle à cet égard. L'utilisation méthodologique de l'Internet et du courriel comporte de nombreux avantages pour la recherche, mais également des écueils à ne pas sous-estimer. Néanmoins, s'adonner à l'étude de communautés de réfugiés disséminés sur la planète en se servant des médias électroniques permet des "dialogues virtuels » qui ouvrent des perspectives nouvelles et fascinantes.

$\Delta$ t the end of 1991, three refugee camps were set up close to the small town of Dadaab in Kenya to host the large influx of Somalis fleeing the collapse of their state. At present, approximately 135,000 refugees are said to live in Ifo, Dagahaley, and Hagadera. Most of them originated from the regions of Jubadda Hoose and Shabeellaha Hoose, the lowlands of the two main rivers in South Somalia. There are also smaller groups of refugees from Ethiopia, Sudan, and Uganda, and a few individuals from Zaire in Dadaab. Between February 1999 and September 2001, I carried out anthropological Ph.D. research in the camps. I wanted to understand how Somali refugees were able to survive in these camps, despite insufficient international aid 
and limited regional opportunities. Dadaab lies in Kenya's Northeastern Province, a vast stretch of semi-arid land that has been the object of dispute between Kenya and Somalia since independence. The area is unsuitable for agricultural production and is mainly occupied by Kenyan Somali pastoralists. The province has a very poor infrastructure and is insecure due to frequent attacks by shifta, Somali "bandits." Inside the camps, UNHCR and various international NGOs provide assistance to the refugees. During my stay in the camps, this assistance often consisted only of three kilograms of maize per person per fifteen days, an amount impossible to survive on. Thus, it was clearly not their only means of survival.

My main aim in studying how Somalis were dealing with refugee life in the Dadaab camps was to provide an alternative perspective on refugees. Refugees are often depicted as "vulnerable victims" or "cunning crooks" in media and academic literature. This stands in sharp contrast to my own experiences with refugees during my work for VluchtelingenWerk (a Dutch organization assisting refugees) and in various research projects. I was introduced to many individuals who were not passively affected by circumstances but rather were resourcefully trying to utilize available opportunities. In my opinion, social scientists should continuously question accepted categories and forms of analysis, within both science and the larger society. This is even more urgent considering the fact that (theoretical) constructs not only are influenced by social reality, but also have an impact on the general discourse within that reality and thus on actions. ${ }^{2}$ The ideas that exist about refugees in the end have a clear effect on the reality of their daily lives. As an alternative to common stereotypes of vulnerability and cunningness, I wanted to provide an image of human complexity. ${ }^{3}$

In order to understand the situation of Somali refugees in Dadaab at present, it is essential to place that specific situation in a historical context. In the academic world as well as within relief-providing organizations, crises are largely seen as external events interfering with a certain stable social reality. This viewpoint obscures the fact that insecurity is the normal state of affairs for many, and people have found their own ways of dealing with it. Before the civil war, Somalis had particular ways of dealing with the insecurities they were faced with, based on assistance networks, mobility, and dispersing investments within those networks. I wanted to understand what effect refugee life in Dadaab had on these existing social security mechanisms. In an earlier study on Somalis in refugee camps, Kibreab ${ }^{4}$ found that their social security arrangements were largely based on precedents. Other research, however, has suggested that major changes take place within refugee com- munities due to life in camps. Harrell-Bond, ${ }^{5}$ for example, has argued that the encounter with humanitarian aid leads to a serious rupture of social structures. I was interested to understand whether, in Dadaab, Somali refugees could still rely on social networks, migration strategies, and a variety of investment strategies for their survival. In short, I call this the "nomadic heritage" of the Somali, though "nomadic" here refers not to a livelihood, but more widely to a way of living.

Soon after my arrival in the camps, I learned about the existence of an extensive, informal system of communication and banking. It is called xawilaad in the Somali language, xawil meaning "transfer," usually of money or responsibility. ${ }^{6}$ The Somalis use xawilaad companies with branches in many countries worldwide to send money to their relatives elsewhere. Overall, huge investments are made in means of communication and transfer, which may be an indication of the importance attached to maintaining strong networks. About 10 to 15 per cent of the refugees in Dadaab receive remittances, enabling the survival of a much larger part of the camp population and simultaneously stimulating development in the area. ${ }^{7}$ Furthermore, stimulated by these remittances and the images that come with them, migration to resettlement countries is a popular investment for the refugees in Dadaab. Facilitated by technological developments in communication and transportation, social security mechanisms that originally developed from local circumstances of life in Somalia have now extended to a global scale. A significant number of Somali refugees in Dadaab are able to assist themselves, irrespective of limited local opportunities and insufficient international aid, because they are part of a network of "transnational nomads."

\section{Methodological Choices}

As earlier stated, an important aim of my research work was to provide an alternative perspective on refugees. ${ }^{8}$ My major objection against current conceptualizations is that they generally do not acknowledge the agency of refugees. I define "agency" as concerning "events of which an individual is the perpetrator, in the sense that the individual could, at any phase in a given sequence of conduct, have acted differently." Agency firstly implies a level of choice, although the conditions under which a certain choice is made may vary. A second aspect of agency involves power: the power of doing things or leaving them, thus making a difference. According to Giddens, this transformative capacity is of importance irrespective of whether the outcome of someone's actions was intended or not. As such, his structuration theory avoids the common dualism between actor or agent and structure or system that is created by the assumption 
that an individual's or group's level of choice and power is constrained by larger institutional structures and social systems. "Structure is not to be equated with constraint but is always both constraining and enabling. This, of course, does not prevent the structured properties of social systems from stretching away, in time and space, beyond the control of any individual actors." 10 Thus, the agency of actors is both enabled through and constrained by the structural properties of social systems, while simultaneously leading to their reproduction. Conversely, structure, while seemingly operating independently and decisive, only exists through the actions of individual agents.

The central importance of the agency of refugees is not only a theoretical but also an epistemological stance and necessarily has to be reflected in the choice of research methods. If one accepts the fact that refugees have and should have a certain level of power and choice in determining their lives and livelihoods, this surely also includes the power and choice to create knowledge about and give meaning to their own situation. Individuals use certain narratives, or discursive means, to reach decisions and justify them. In most cases, there are various types of discourse to choose from, so people face alternative ways of representing themselves, formulating their objectives and acting. I do not feel I am occupying a privileged position as researcher; I necessarily influence the communication and knowledge-creation process as others do, and intervention occurs both ways. Academic knowledge creation thus takes place through the "dialectics of a dialogical ideal."11 In my opinion, it can best be practiced through dialogue between refugees, agencies, and academics; through the exchange and discussion of ideas, concepts, and theories. ${ }^{12}$

I have tried to actively involve Somali refugees, policy makers, and practitioners in both data collection and analysis, for which in particular various participatory approaches have proven relevant. Participatory research developed in the 1960s from a wish to counter the traditional subject-object approach, which was seen to be hierarchical and "exploitative."13 Rather, these approaches and methods tried to work from a more equal perspective, in which the research and research results should be of use to all those involved, often leading to subsequent action for change. Discussions with refugees in Dadaab on my research questions and methods proved vital for my fieldwork and research assistants have played an active and independent role in collecting data. Besides, throughout the fieldwork I have engaged in multiple dialogues relating to my data and various stages of analysis. This included sharing and discussing interview reports, fieldwork reports, and later papers and preliminary chapters of the thesis with Somalis, policy makers, and implementers as well as academics both in Dadaab and elsewhere. It also included organizing sessions to discuss my research findings and writings, during which my analyses were challenged on a number of occasions. These challenges and the way I have tried to deal with them were essential in shaping my analysis.

\section{Virtual Dialogues: Internet Dissemination and E-mail Exchanges}

After I "came back from the field," I continued to engage in this dialogical approach through electronic media. There is a wealth of information on the Internet for Somalis, with well over eighty Somali sites. ${ }^{14}$ These sites provide written and oral information on the latest developments in Somalia, calls for tracing people, business, world news, and so on. They offer a space for Somalis all over the world to discuss issues related to, among other things, culture, religion, the war, and being refugees and immigrants. The sites also enable them to share their knowledge and experience of life in a certain place with others. Some of the sites include newspapers and audio and video material of, for example, BBC Somali Service and the Somali radio in Sweden or Canada, which otherwise would not have been widely accessible. The Internet allows Somalis around the world to have access to up-to-date community information and at the same time enables them to exchange messages with individuals elsewhere. In this way, e-mail user groups and Web sites have even played a role in economic reconstruction as well as in political processes in Somalia. ${ }^{15}$ It is clear that these technological developments may greatly affect social relations within refugee diasporas. The Internet and e-mail enable personal relations within transnational communities to be more frequent and thus more mundane and taken for granted. ${ }^{16}$ Far from being "virtual," computer-mediated communication is yet another means of social contact between people at a distance from each other. It enables the direct involvement of members of a diaspora in each other's lives.

The development of electronic media is a very interesting research field when studying refugee diasporas. At the same time, in my opinion, the Internet and e-mail are vital in developing methodological tools for transnational research. I do not agree with Hannerz ${ }^{17}$ when he states that methodologically, transnational anthropology can hardly be characterized by any one set of approaches that would distinguish it from other anthropology. Existing approaches are certainly not sufficient, and various researchers attempt to transcend them. In such an exploratory phase, "the key to doing research in complex transnational spaces devolves less from methods, multidisciplinary teams or theoretical frameworks_-although these are, of course, important-than from the suppleness of 
imagination." 18 It is important to develop sound methodological tools using the Internet and e-mail, partly based on existing methodological techniques but maybe also imagining new approaches. Electronic media, for example, support group discussions amongst people in different locations, enable anonymous interviews, and also facilitate a large-scale questionnaire or creative web-assignment (through pictures, essays, etc.). Furthermore, electronic media enable the dissemination and discussion of preliminary analysis of research data, either indiscriminately or amongst a select group of people.

\section{Dialogues with the Somali Diaspora}

In my own research, I mainly experimented with this last option, in an attempt to continue a dialogical approach towards knowledge creation. I contacted a number of Somali sites, introducing my research in Dadaab and sending them some of my work. Somalinet published my field reports, and added a "Forum Discussion." ${ }^{19}$ Here, anybody could respond (anonymously or including his/her e-mail address) to the writings. Interesting debates followed, in which I personally also contributed to the Forum Discussion a number of times in order to respond to various comments. In a few cases, the discussions went on in the less public space of e-mail. Somalinet then published a preliminary version of the first chapter to my thesis, adding my e-mail address and encouraging readers to send their remarks to me. Furthermore, I sent a number of my writings to a UNHCR staff member, who invited me to have them published as a working paper, appearing both on the Internet site and in hard copy. ${ }^{20}$ This gave me feedback from policy makers, UN or NGO staff, and researchers. I thus built up a list of e-mail addresses of a very specialized group of interested readers, combining Somalis in the diaspora with refugee "specialists," and decided to utilize that resource.

Starting up a mailing list, I introduced my initiative as follows:

Some days ago, a Somali student at Melbourne University asked me whether I had ever thought about 'setting up a group of Somali people living around the world to give you advice on the methods you use, the areas you need to do more research on, or any other support you may need'. At the same moment, I was going through some articles on diasporas, transnationalism and global networks. In many of these articles it was suggested that research in this field should be carried out within a transnational, trans-disciplinary network that consists of academics, practitioners, policy makers, and the 'transnational migrants' themselves. I fully agree. The suggestion was brilliant and perfectly timed.
I would send any of my writings through this mailing list, and had discussions with its individual members on my writings and other topics. Thus, I learned much more about the position of Somalis in the diaspora and was even contacted by a number of refugees who had lived in Dadaab, some of whom I had met, and who were now building up there lives elsewhere.

Abukar Rashid, for example, with whom I had worked in Hagadera, contacted me while he was in Nairobi, waiting for his ticket to Canada. ${ }^{21}$ We had not exchanged addresses, but he was surfing the Net when he found my writings and e-mail address. When Abukar arrived in Canada he contacted me again, and kept me informed about his new life. We stayed in touch, and he was the person who advised me to send one of my more politically engaged articles, on the closure of xawilaad offices in the aftermath of September 11, 2001, to Hiiraan.com. When I did, it was immediately published, and the responses were overwhelming. In the first few days, I received over ten e-mails a day. It seemed that taking a stance so firmly to "support the Somali case" and condemn the actions of the U.S. government against certain xawilaad offices really had an impact. I had clearly positioned myself, taking sides, and this was appreciated. More work was published on Hiiraan, and I got in touch with a number of very qualified and experienced Somalis, many of them highly educated and in good positions in their new countries.

To further illustrate the incredible value of electronic media for data collection and analysis, and give an impression of the kinds of dialogues that took place "in cyberspace," I have selected sections from the electronic dialogues I had with Aden Yusuf. Aden works as a program analyst for a state health department in the U.S. and has an M.A. in development economics. He was born in central Somalia, lived in Kenya for many years, and now feels rather settled in the U.S., where he stays with his wife and three children. Aden initially responded to the article on the closure of the xawilaad that I had sent to the Hiiraan website. From there, our dialogues took off. I sent him my various writings and he sent me relevant newspaper articles and Internet links. He also gave me his detailed feedback on all preliminary chapters of my thesis and came with many examples of the arguments I wanted to make. I asked him (and others) for advice when I was struggling to correctly reproduce certain Somali words or practices. We had fascinating discussions, for example on the Somali sense of transnationalism that was so central in my work.

He writes:

I always wonder what are the allegiances of a Somali (religion? clan? nation? state?). One could argue that the only allegiance 
that a Somali has is that of the clan. But paradoxically that allegiance is highly segmented right down to the level of 'myself versus my half-brother'. You know where clan begins, but you never know where it ends. The Somali is a complex individual ... I agree with your thesis that the Somali nomadic background primarily explains their strong sense of kinship networking, high mobility and dispersing of investments. Somalis tend to be always on the run, chasing water and grazing wherever they can find it; international borders never restrain them. Imagine that civil war breaks out in Kenya, God forbid. Would a Kikuyu farmer cope in the same way as a Somali nomad would? The answer is no. Somalis are very mobile, as your thesis would support. They leave their homes, lands and country altogether. With regard to allegiances, I would add that Somalis, in general, do have little commitment to land. I know a Kikuyu has a strong sense of loyalty to land. For Kikuyu, land has a sentimental and non-quantifiable value. The Somali, on the other hand, have less emotional attachment to the land. 'If it does not rain here, I will move there'. They are very pragmatic people.

These and many other comments by and debates with Somalis across the diaspora have deepened my understanding of the issues I was trying to tackle during my fieldwork in Dadaab.

\section{Advantages and Pitfalls}

The methodological use of the Internet and e-mail in research amongst refugee diasporas has a number of advantages. In the first place, electronic media have become communication and knowledge-exchange tools of increasing importance, also for refugees. For a refugee diasporic community, an Internet site is much easier and more commonly set up than a broadcasting station. Besides, once it has been set up, anybody can contribute information from anywhere with little effort. Whereas it is difficult to have access to broadcasting on radio and especially television, on-line media allow easier access and are non-linear, largely non-hierarchical, and relatively cheap. ${ }^{22}$ The Internet is also more likely to have an effect on "real life events" since it is interactive within small time spans. As such, it is not only an important study site, but should also be explored in terms of methodological value. "Participant observation" on the Internet might be a very valid technique to enable dialogical approaches towards knowledge creation that have transformative potential.

A second advantage of the use of electronic media in transnational research is related to the diasporic nature of the refugee communities concerned and the relative mobility of the individuals involved. "Virtual exchanges" do not require long-term residence in a particular geographical place, which was very important in my own research. How, for example, to keep track of a Somali "transnational nomad" who, in the course of a few months, lives in Australia, visits his relatives in Kenya and the U.S., frequently goes to Dubai on business trips, and finally decides to leave Australia "permanently" for the United Arab Emirates?23 A further advantage is that Internet users do not have to worry about social status and power differences, since interaction on the Net does not provide the same social-context cues that face-to-face interaction provides. ${ }^{24}$ This may create a safe environment for antagonistic parties to have open discussions, as Kadende-Kaiser found in her research amongst Hutu and Tutsi Burundians. It can also offer a secure space for communication between the researcher and members of the diaspora involved, where class, race, gender, or age remains unclear and thus interferes less in the discussions.

This is, however, at the same time a major disadvantage, as it makes contextualization of the provided information difficult. Information that is gained through observation during fieldwork is unavailable and might have to be explicitly asked for. Critics are concerned that, as a consequence, it also becomes more difficult to check the information. According to them, people will be far more inclined to tell lies when communicating electronically, and there is no way the researcher is able to verify their stories. Yet it has also been argued that people are actually more inclined to tell the truth when communicating anonymously. The question is whether face-to-face interaction really provides better guarantees against lies. I personally doubt this, but agree that the use of electronic media for research should always be coupled with actual fieldwork. It is vital to have a sound understanding of the refugee community before engaging in virtual dialogues. At the same time, it is likely that the researcher will continue to move back and forth between the "virtual" and "real" worlds, and the two may come together in various ways. Somalis whom I met in Dadaab but lost touch with have contacted me by e-mail; also, I have phoned and met a number of people around the world whom I was introduced to electronically.

Maybe the most disturbing pitfall of research through the electronic media is the likely bias created by it. It can be assumed that Internet users are usually relatively highly educated or young and more often male than female. In terms of their global location, access is far more available in Western countries and in urban spaces. ${ }^{25}$ Thus, it is not unlikely that important sections of the refugee diaspora will be excluded and the research will present a partial narrative only. Again, this illustrates the fact that this type of research should always be combined with (multi-)sited fieldwork. But actually, the partiality of all transnational research, which always involves a trade-off between dispersion and 
intensity, ${ }^{26}$ is commonly acknowledged. As this type of research focuses on the links between various localities, including a number of these localities in research often has consequences for the level of depth with which fieldwork can be undertaken. As more research results will become available on the use of the Internet by different communities, more insight can also be gained into the exact level of biasedness when relying on electronic methodologies, and the risk of a large gap between "reality" and "virtuality." Most likely, such methodologies may be very appropriate for research amongst some refugee diasporas and not for others, depending on their level of widespread and active use of the Internet and e-mail. ${ }^{27}$

\section{Conclusion}

"Distance" seems to be an important issue in the current discussions on methods for studying forced migration. This "distance" firstly refers to the detachment that supposedly exists between researchers and the people they study, for example expressed in calls for "surveys based on representative samples of the target population". ${ }^{28}$ Yet such distance has proven unacceptable for me during my research in Dadaab. Being confronted with the often inhuman circumstances under which refugees had to live and at times asking questions that triggered painful memories, detachment was improbable and also felt highly inappropriate to me. Secondly, "distance" relates to the assumption that, after data collection, the researcher needs physical as well as mental distance to analyze his or her fieldwork material objectively and to write about it. Yet this involves a kind of appropriation of information that in recent years many social scientists have questioned. Various attempts have been made to deal with the ethical questions raised and more participatory ways of analysis and publication have developed in the process. ${ }^{29}$ I have illustrated how I chose a dialogical approach towards knowledge creation that did not allow for such distance but rather accepted the obvious power and choice that refugees (should) have to create knowledge about and give meaning to their own situation.

Global developments in transportation and communication have shortened the actual time-space distance between the researcher and the people concerned, facilitating participation in the analysis and writing down of results. Refugees around the world influence and are influenced by what has been written about them, and thus there is no clear distinction between various "types" of knowledge. Throughout my research, I have found it important to further stimulate and be consciously aware of these exchanges between refugees, policy makers, and academics. Electronic media have greatly assisted me in this. As shown in this article, the Internet firstly provides a large source of information about specific refugee communities and the effect of electronic media on refugee diasporas would be a very interesting field of research. Secondly, these media can assist in data collection, as they are ideal for gathering information from a widely spread and highly mobile community, or for stimulating group discussions within a refugee diaspora. Finally, electronic media like the Internet and e-mail are very easy and fast ways of disseminating and discussing findings amongst refugees, policy makers, and implementers as well as academics. Especially when the research process is dialogical and transformative, fully accepting the agency of refugees, such virtual dialogues provide a very important addition to more common, (multi-)sited forms of research.

\section{Notes}

1. J. Crisp, "A State of Insecurity: The Political Economy of Violence in Refugee-Populated Areas of Kenya" (Working Paper No. 16, UNHCR, Geneva, 1999).

2. E. Wolf, "Perilous Ideas: Race, Culture, People," Current Anthropology 35, no. 1 (1994): 1-12.

3. C. Horst, "Inspiration in Transformation: Beyond 'a Better World," in Making Waves: Inspiring Critical and Feminist Research, A Tribute to Joke Schrijvers, ed. E. Lammers (Amsterdam: Aksant, 2002): 86-90.

4. G. Kibreab, "The Myth of Dependency among Camp Refugees in Somalia," Journal of Refugee Studies 6, no. 4 (1993): 321-49.

5. B. Harrell-Bond, Imposing Aid: Emergency Assistance to Refugees (Oxford, New York, and Nairobi: Oxford University Press, 1986).

6. See also C. Horst and N. Van Hear, "Counting the Cost: Refugees, Remittances and the "War against Terrorism,"' Forced Migration Review 14 (2002): 32-34.

7. C. Horst, Transnational Nomads: How Somalis Cope with Refugee Life in the Dadaab Camps of Kenya (Oxford and New York: Berghahn Books, forthcoming).

8. For an exact description of research methods during fieldwork, see ibid. My aim here is to outline underlying principles, in particular in relation to the use of electronic media.

9. A. Giddens, The Constitution of Society (Cambridge: Polity Press, 1984), 9.

10. Ibid., 25.

11. J. Schrijvers, "Dialectics of a Dialogical Ideal: Studying Down, Studying Sideways and Studying Up," in Constructing Knowledge: Authority and Critique in Social Science, eds. L. Nencel, and P. Pels (London: Sage, 1991): 162-79.

12. Many researchers have experimented with similar practices, but I have been particularly inspired by M. Jackson, At Home in the World (Durham: Duke University Press, 1995), describing research amongst Aborigine communities in Australia.

13. From the 1980 s onward, this has also been an important issue within feminist writing. See e.g. P. Caplan, "Engendered Knowledge: the Politics of Ethnography," Anthropology Today 4, no. 5 \& 6 (1988): 8-12 and 14-17; T. Chanter, "Postmodern 
Subjectivity," in A Companion to Feminist Philosophy, ed. A. Jaggar and I. Young (Oxford: Blackwell Publishers, 1988): 263-71; D. Haraway, "Situated Knowledges: The Science Question in Feminism and the Privilege of Partial Perspective," in Simians, Cyborgs and Women: The Reinvention of Nature (New York: Routledge, 1991): 183-201; C. Mohanty, A. Russo, and L. Torres. Third World Women and the Politics of Feminism (Bloomington and Indianapolis: Indiana University Press, 1991).

14. See, for a good overview of links, $<$ http://www.hiiraan.com/ $>$.

15. Menkhaus and Prendergast in D. Griffiths, "Fragmentation and Consolidation: The Contrasting Cases of Somali and Kurdish Refugees in London," Journal of Refugee Studies 13, no. 3 (2000): 281-302.

16. D. Miller and D. Slater, The Internet: An Ethnographic Approach (Oxford: Berg, 2000), 6.

17. U. Hannerz, "Transnational Research," in Handbook of Methods in Anthropology, ed. H. Russell Bernard (Walnut Creek, CA: Altamira Press, 1998): 235-53.

18. P. Stoller, "Globalizing Method: The Problems of Doing Ethnography in Transnational Spaces," Anthropology and Humanism 22, no. 1 (1997): 91.

19. Somalinet (<www.somalinet.com $>$ ) has greatly reorganized since that time, and the Forum Discussion I mention is no longer available on the Internet.

20. C. Horst, "Vital Links in Social Security: Somali Refugees in the Dadaab Camps, Kenya," (Working Paper No. 38, UNHCR, Geneva, 2001).

21. Names have been changed so as to respect the privacy of informants.

22. K. Karim, "From Ethnic Media to Global Media: Transnational Communication Networks among Diasporic Communities," (Transnational Communities Programme Working Paper Series, Oxford, 1999), 12.

23. V. Mazzucato, R. v. Dijk, C. Horst, and P. de Vries, “Transcending the Nation: Explorations of Transnationalism as a Concept and Phenomenon," in Globalization and Development: Themes and Concepts in Current Research, ed. D. Kalb, W. Pansters, and H. Siebers (Dordrecht, Boston, and London: Kluwer Academic Publishers, 2004): 151-52.
24. R. Kadende-Kaiser, "Interpreting Language and Cultural Discourse: Internet Communication among Burundians in the Diaspora," Africa Today 45, no. 3/4 (1998): 121-48.

25. V. Mazzucato, R. v. Dijk, C. Horst, and P. de Vries, 153.

26. U. Hannerz.

27. Research amongst migrant communities in the Twin Cities, Minnesota, indicates that the Somali community's use of the Internet is relatively high (42 per cent), compared to other migrant groups. See P. Mattessich, Speaking for Themselves: A Survey of Hispanic, Hmong, Russian and Somali Immigrants in Minneapolis-Saint Paul (Saint Paul, MN: Wilder Research Center, 2000).

28. K. Jacobsen and L. Landau, "Researching Refugees: Some Methodological and Ethical Considerations in Social Science and Forced Migration," (Working Paper No. 90, UNHCR, Geneva, 2003); emphasis added.

29. See e.g. M. Jackson, At Home in the World (Durham: Duke University Press, 1995).

Dr. Cindy Horst works as a researcher and lecturer in refugee studies at the Amsterdam Institute of Metropolitan and International Development Studies (AMIDSt), a research institute within the University of Amsterdam. Her interests mainly focus on the transnational livelihoods of Somali refugees, including their remittance-sending responsibilities and migration strategies. She has carried out extensive fieldwork in refugee camps in Kenya as well as in Minneapolis, MN, on this theme, leading to various publications. Her book Transnational Nomads: How Somalis Cope with Refugee Life in the Dadaab Camps of Kenya will be published by Berghahn Books in 2005. Currently, Dr. Horst also works as moderator of the Refugee Livelihoods Network (RLN), which is a UNHCR initiative. The RLN was initiated with the aim of increasing knowledge of the livelihood strategies of refugees and the constraints they face in the process. By enhancing understanding, the project hopes to contribute to more effective policies towards refugee self-reliance, especially in protracted refugee situations. 